DOI https://doi.org/10.21697/ucs.2021.27.1.01

\title{
WĘDRUJĄC ZE SWOIM, OBCYM I WROGIEM. WSTĘP REDAKTORÓW TOMU
}

W trakcie uroczystości przyznania tytułu doktora honoris causa Uniwersytetu Jagiellońskiego Ryszard Kapuściński (1932-2007) wygłosił wykład, którego tytuł brzmiał: Spotkanie z Innym jako wyzwanie XXI wieku (Kapuściński 2006: 63-76). Podróżnik, dzieląc się swoimi przemyśleniami o wyzwaniach, jakie stoją przed ludzkością, oraz wskazując na przemiany także w spojrzeniu na inność, zauważył: „dziś jednak idę przez wieś w górach Etiopii, biegnie za mną gromada dzieci pokazujących mnie palcem, rozbawionych i wołających: Ferenczi! Ferenczi!'To znaczy właśnie - obcy, inny. Bo to ja dla nich jestem Inny. W tym sensie wszyscy jedziemy na tym samym wozie. Wszyscy mieszkańcy naszej planety jesteśmy Inni wobec Innych - ja wobec nich, oni wobec mnie" (Kapuściński 2006: 70-71). Zarówno w przeszłości, jak i współcześnie w sytuacji realnego lub domniemanego zagrożenia, w dynamicznych stosunkach i relacjach międzynarodowych, międzykulturowych, międzyreligijnych, międzyludzkich figury Innego, zmiany na pozycjach obcości, swojskości, wrogości są odczuwalne także w życiu codziennym. Warto zatem na nowo podejmować naukową refleksję i badania Innego: Swojego, Obcego, Wroga także w kontekście współczesnej mobilności: w ruchu, w drodze, wędrówce, podróży, pielgrzymce; w procesie współczesnych zmian i przeobrażeń historycznych, kulturowych, psychologicznych i społecznych. Uwzględniając bowiem dotychczasowe wyniki refleksji naukowych na temat zjawiska wyobcowania, swojskości i wrogości, należy stwierdzić, że Swoim, Obcym i Wrogiem może stać się każdy - metaforycznie nawet „koronawirus” - kto w kulturowym dyskursie zakłada maski, ewoluuje, zmienia pozycje i miejsca lub zwyczajnie - wyraża swoje opinie i przekonania.

Zapraszamy do interdyscyplinarnej i wieloaspektowej analizy zjawiska swojskości, obcości i wrogości w okresie nieustannych zmian i w różnych kontekstach: historycznych, kulturowych, społecznych, psychologicznych, antropologicznych, które zaproponowaliśmy w niniejszym numerze „Uniwersyteckiego Czasopisma Socjologicznego” / „Academic Journal of Sociology”. Znalazły się w nim artykuły, których tezy zostały zaprezentowane w trakcie ogólnopolskiej i interdyscyplinarnej konferencji naukowej pt. „Wędrując ze Swoim, Obcym i Wrogiem: Historia - Kultura - Społeczeństwo” zorganizowanej 11 marca 2021 roku przez Instytut Nauk Socjologicznych Uniwersytetu Kardynała Stefana Wyszyńskiego w Warszawie oraz Instytut Studiów Międzykulturowych Uniwersytetu Jagiellońskiego. Dyskusje w jedenastu panelach, z konieczności przeprowadzone w przestrzeni wirtualnej, stanowiły kontynuację dwóch wcześniejszych spotkań naukowych o tej tematyce. Pierwsza konferencja odbyła się w 2016 roku, a druga w 2018 roku - obie w Warszawie. Ich trwałym efektem są dwa tomy publikacji: Obcy w labiryncie kultur, pod redakcją Tomasza Michała Korczyńskiego i Anny-Marii Orla-Bukowskiej [Warszawskie Wydawnictwo Socjologiczne, Warszawa 2016] oraz Swój-Obcy - Wróg. Wędrówki w labiryntach kultur, pod redakcją Tomasza Michała Korczyńskiego [WN Katedra, Gdańsk 2018].

Trzecie spotkanie zgromadziło ponad dwustu uczestników. Było wśród nich 55 badaczy i badaczek prezentujących wyniki swoich badań związanych z problematyką obcości ujawniającej się w rozmaitych wymiarach mobilności. W ujęciu antropologicznym, filozoficznym, historycznym, kulturoznawczym, literaturoznawczym, pedagogicznym, religioznawczym, socjologicznym. Przedstawiono tematy związane zarówno z konkretnymi przestrzeniami (Bułgaria, Grecja, Litwa, Serbia, Szwajcaria, Turcja, Wietnam, Włochy), jak i przestrzenią wirtualną, grupami narodowymi (Irish Travellers, Polacy, Rosjanie, Ukraińcy) i etnicznymi (Cygani/Romowie, Żydzi), mniejszościami seksualnymi, twórczością Egona Bondego, Stanisława Cata-Mackiewicza, Michela Houellebecqa, Alda Novego, Andrzeja Stasiuka, Jeana-Philippe’a Toussainta, Ireny Wyczółkowskiej. Oddzielny blok stanowiły wystąpienia podejmujące problematykę obcości, inności i wrogości w edukacji. Prelegenci reprezentowali 
25 uczelni i jednostek naukowych, w tym m.in. Uniwersytety: Warszawski, Jagielloński, Wrocławski, Łódzki, Opolski, Śląski, Rzeszowski, Kard. Stefana Wyszyńskiego w Warszawie, im. Adama Mickiewicza w Poznaniu, Mikołaja Kopernika w Toruniu, Marii Curie-Skłodowskiej w Lublinie, a także SWPS Uniwersytet Humanistycznospołeczny w Warszawie, Uniwersytet Pedagogiczny im. KEN w Krakowie, Uniwersytet w Białymstoku, Chrześcijańską Akademię Teologiczną, Akademię Pomorską, Akademię Sztuki w Szczecinie, Państwową Wyższą Szkołę Informatyki i Przedsiębiorczości w Łomży, Wyższą Szkołę Gospodarki Euroregionalnej.

W tym numerze prezentujemy trzy rozwinięte do formy artykułów naukowych głosy wspomnianej debaty. Pierwszy z nich należy do Artura Golaka, który analizuje wizerunek żołnierzy rosyjskich prezentowany na kartach literatury wspomnieniowej z początku I wojny światowej. W tym przypadku mowa jest o krótkotrwałej zmianie w stereotypowym postrzeganiu obcego $\mathrm{w}$ sytuacji przemieszczania się rosyjskiego wojska, relacji z cywilami, a także prezencji żołnierskiej Rosjan. Autor wskazuje na te elementy rzeczywistości społeczno-politycznej, które ów wizerunek kształtowały zarówno w indywidualnych ocenach, jak i zapisanych obserwacjach reakcji społecznej Polaków pozostających pod zaborami.

W swoim artykule Antonina Pawłowska prezentuje interesujące - zwłaszcza dla polskiego odbiorcy - naukowe dociekania o pochodzeniu i historii Irish Travellers. W analizie historiograficznej autorka nie tylko przedstawia stan badań nad tą grupą etniczną, ale wskazuje na ich społeczny wpływ i zmieniające się opinie w irlandzkim i brytyjskim dyskursie. Ten ważny głos oparty na studium historii konkretnej grupy dowodzi społecznej odpowiedzialności badaczy - także w doborze metod i wykorzystaniu źródeł. Aktywność samych Pavees, w ramach rozmaitych organizacji, to z kolei przykład dehierarchizacji świata i kultur, także w odniesieniu do środowiska naukowego.

Z kolei Tomasz Koper skoncentrował swój artykuł wokół utrwalonych kulturowych wyobrażeń o nomadycznej i półnomadycznej mobilności Cyganów. Oprócz syntetycznego historycznego zarysu wędrówek taborów cygańskich, autor wskazał na prawne i polityczne źródła postrzegania i traktowania członków tej grupy jako Obcych i Wrogów.

Do głosu w dyskusji nad promowanym w naszym czasopiśmie zagadnieniem wpływu, jaki polska kultura miała i ma na światową kulturę, dołączył prof. Waldemar Czajkowski. Autor w swej glosie zaznacza, że będąc zwolennikiem pluralizmu metodologicznego, uważa, że style uprawiania historii filozofii są komplementarne, a nie alternatywne, i jego tekst ma charakter opisowy, skupiający się głównie na twórcach ostatnich dwóch stuleci, a nie na ich dziełach.

Aleksandra Gardian omawia styczniowe spotkanie z cyklu „Economic Lunchtime Seminars” w 2021 roku, bardzo oczekiwane przez studentów Uniwersytetu Kardynała Stefana Wyszyńskiego w Warszawie.

Tradycyjnie znaleźliśmy w naszym numerze miejsce dla recenzji wydawniczej. Jej Autorem jest prof. Józef Baniak, który omówił książkę ks. prof. dr. hab. Janusza Mariańskiego pt. Aforyzmy, myśli, sentencje i refleksje socjologiczne. (Religia - Kościót-moralność-wartości-godnośćludzka-sens życia). Wydawca: Wyższa Szkoła Nauk Społecznych z siedzibą w Lublinie, Lublin 2020, ss. 410.

$\mathrm{Na}$ końcu zaproponowaliśmy wypowiedź zastępcy redaktora naczelnego UCS dr. Marcina Choczyńskiego, który omówił rozwój oraz perspektywy dla naszego czasopisma.

Przywoływany na początku Ryszard Kapuściński w innym miejscu ubolewał: „Jakże trudnym wyzwaniem stały się postępy komunikacyjne ostatnich dziesięcioleci. Z jednej strony one na pewno nas przybliżają do siebie, ale czy naprawdę zbliżają ? Między człowieka i człowieka, między Ja i Innego wprowadzono technicznego pośrednika - iskrę elektryczną, impuls elektroniczny, sieć, łącze, satelitę [...] Ja przekazywało się Innemu nie tylko w słowie, ale również swoją bliskością, bezpośredniością, byciem razem. Tego doświadczenia, tego przeżycia nic nie jest w stanie zastąpić" (Kapuściński 2006: 60). Globalna sytuacja z przełomu 2020 i 2021 roku w wielu społeczeństwach i grupach nie tylko przyczyniła się do powstania kolejnych wymiarów zarówno swojskości, jak i obcości, wrogości, ale także stała się okazją do zadania pytań o jakość zbliżenia człowieka i człowieka, Ja i Innego oraz konsekwencji braku i/lub coraz większych ograniczeń bezpośredniości kontaktów. 
Wypada mieć nadzieję, że kolejne spotkanie poświęcone problematyce Swojego, Obcego, Wroga odbędzie się już w warunkach bliskości badaczy i uczestników oraz że uwzględnione w nim będą studia i badania nad innością w świetle owej „niezastępowalności” bycia razem.

\section{Bibliografia}

Kapuściński R. (2006), Ten Inny, Kraków: Wydawnictwo Znak. 